\title{
AVALIAÇÃO DE PRÁTICAS DE RESPONSABILIDADE SOCIAL CORPORATIVA EM SUPERMERCADOS DE NATAL-RN.
}

\section{ANALISIS OF CORPORATE SOCIAL RESPONSIBILITY WITHIN SUPERMARKETS FROM NATAL-RN, BRAZIL}

\author{
Handson Cláudio Dias Pimenta ${ }^{1}$; Ana Clézia Simplício de Morais ${ }^{2}$; \\ ${ }^{1}$ Instituto Federal de Educação, Ciência e Tecnologia do Rio Grande do Norte - IFRN - Natal \\ handson.pimenta@ifrn.edu.br \\ ${ }^{2}$ Universidade Federal do Rio Grande do Norte - UFRN - Natal - Brasil \\ clezia_ecologia@yahoo.com.br
}

\begin{abstract}
Resumo
O setor de supermercados, um ramo importante do varejo nacional, vem crescendo bastante nos últimos anos em termos de faturamento, expansão e atuação social. Na cidade de Natal isso não é diferente e faz-se, portanto, necessário saber como o setor tem trabalhado a responsabilidade social corporativa (RSC) de modo a contribuir com o desenvolvimento sustentável. Assim sendo, o presente trabalho aborda um estudo com algumas lojas de supermercados atuantes em Natal-RN (local e nacional) e tem o objetivo de avaliar as práticas de responsabilidade social desenvolvidas supermercados como uma forma de construir a sustentabilidade. Para tanto, foram aplicados questionários junto aos gestores de quatro redes de supermercado - sendo duas redes locais e duas nacionais - para coleta de informações a respeito da Responsabilidade Social Corporativa - RSC (práticas de RSC voltadas ao público interno, ao público externo e ao meio ambiente). Verificou-se que não existem grandes diferenças entre o desempenho das lojas locais e nacionais, nem padrões definidos da gestão da RSC entre estes grupos de supermercados foi verificado. As ações de RS desenvolvidas pelos supermercados estão voltadas, de uma forma geral, para atender demandas específicas, trabalhando para minimizar/aliviar problemas da sociedade e não para saná-los de forma definitiva, entretanto, são de papel essencial constituindo-se como exemplo para as demais empresas do ramo.
\end{abstract}

Palavras-chave: sustentabilidade empresarial; responsabilidade social corporativa; indicadores de sustentabilidade; supermercados.

\section{Introdução}

A Responsabilidade Social e a sustentabilidade são temáticas que vem ganhando destaque no mundo corporativo (CARDOSO, 2008) e isso vem crescendo fortemente no ramo varejista, sobretudo em supermercados (ALIGLERI, 2008).

Destaca-se que o setor de supermercados, um ramo representativo do varejo nacional, vem crescendo bastante nos últimos anos. Por exemplo, no estado do Rio Grande do Norte, em 2005 o setor cresceu 32\% alcançando um faturamento médio de 1,6 bilhão no ano de 2005 (SET, 2006). 
Tanto crescimento traz consigo a propulsão do desenvolvimento socioeconômico, considerando que a expansão do setor supermercadista gera arrecadação - que alcançou $\mathrm{R} \$ 765,8$ milhões em 2005 no estado do RN (SET, 2006) - e um elevado número de postos de emprego no local em que são instalados os supermercados.

Dessa forma, a atuação social deste setor deve ser cada vez mais ampliada em suas múltiplas relações com stakeholders, sendo necessária uma atenção especial para este aspecto na atual corrida pela sustentabilidade para melhor se posicionar no mercado. Dentro do âmbito das possibilidades de atuação do setor supermercadista no que tange ao aspecto social há inúmeros indicadores possíveis de serem verificados considerando três ambientes principais: o público interno, composto basicamente por colaboradores/funcionários, fornecedores e clientes; o público externo, composto pelo governo e comunidade e o componente ambiental, que atua de forma transversal ou que engloba os demais componentes de interação social ligado aos aspectos ecológicos (DELAI; TAKAHASHI, 2008; FURTADO; PENA, 2007).

Os supermercados são agentes transformadores e colaboradores da sociedade influenciandoa sob diversos aspectos através de sua relação com os stakeholders, e há uma necessidade urgente da conscientização deste papel por parte dos gestores para que o potencial de desenvolvimento da responsabilidade social corporativa seja explorado.

Assim, abre-se, uma oportunidade de atuação social pelas empresas como um componente diferencial de mercado e da busca pela sustentabilidade através de uma mudança de postura que avance no sentido da Responsabilidade Social, seja com seu público interno e externo, ou através do respeito ao meio ambiente. Dessa forma, o posicionamento das empresas na sociedade, conforme expõe Schroeder e Schroeder (2005), deve ir além de suas atividades tradicionais, passando a envolver também a responsabilidade com o bem-estar social do homem, não valendo somente atuar no provento de bens e serviços, mas buscar contribuir com a qualidade de vida.

Nessa conjuntura, o presente estudo tem como objetivo geral avaliar as práticas de responsabilidade social desenvolvidas pelas lojas de supermercados de Natal-RN, como uma forma de promover a sustentabilidade empresarial. Para tanto, será avaliado a percepção de gestores quanto ao grau de importância dado às questões de responsabilidade social empresarial e o nível de maturidade das práticas de responsabilidade social nas redes de supermercados visitadas e analisar a importância da Responsabilidade Social Corporativa.

O presente trabalho abordará inicialmente uma fundamentação teórica estruturada. Em seguida o trabalho aborda a metodologia da pesquisa, apresentando a caracterização e delimitação da pesquisa bem como os instrumentos de coleta e análise dos dados. Para finalizar, são apresentados os resultados obtidos com a pesquisa e as discussões pertinentes a cerca dos resultados mais relevantes, bem como as considerações finais do trabalho. 


\section{Políticas públicas ambientais: conceitos, princípios e instrumentos}

$\mathrm{O}$ aspecto social que contempla a sustentabilidade empresarial centraliza-se no relacionamento da empresa com suas partes interessadas - stakeholders - de forma a alcançar melhores resultados no seu desempenho e atuação social e objetivando, sobretudo, o ideal maior do desenvolvimento sustentável, que é a melhoria da qualidade de vida para todos. Esse relacionamento deve ser baseado na ética como orientadora das ações e relações com o público, ultrapassando, portanto, obrigações legais e questões de filantropia e, além disso, deve estar firmado de acordo com seus valores, política, cultura e visão estratégica (ORCHIS; YUNG; MORALES, 2002).

Conforme Primolan (2004), a responsabilidade social é um fator decisivo na manutenção da sustentabilidade empresarial, assim cresce a necessidade da responsabilidade social com fins para diminuir os problemas sociais, para que a empresa alcance então o seu espaço no mercado e mantenha sua sustentabilidade.

Dessa forma, o aspecto social da sustentabilidade relaciona-se diretamente com os aspectos econômicos e ambientais, pois são as múltiplas relações sociais que atuam para o desenvolvimento econômico e que influenciam na proteção ou degradação da natureza.

O conceito de responsabilidade social é bastante diverso e vem sendo discutido desde a década de 50 e, atualmente, vem ganhando cada vez mais espaço no meio acadêmico (PRIMOLAN, 2004). Em uma perspectiva histórica Pereira e Filho (2007), fazem um apanhado das correntes teóricas e dos modelos conceituais dentro da evolução do conceito de RSC - Responsabilidade Social Corporativa. Destacaremos, portanto, os três campos conceituais abordados por tais autores para tratar da evolução dos conceitos de responsabilidade social corporativa (Quadro 01).

De um modo geral, a responsabilidade social corporativa pode ser expressa através de "estratégias pensadas para orientar as ações das empresas em consonância com as necessidades sociais, de modo que a empresa garanta, além do lucro e da satisfação de seus clientes, o bem estar da sociedade" (DIAS, 2008, p. 154).

Quadro 1- Modelos conceituais da evolução do conceito de RSC

\begin{tabular}{|c|c|}
\hline Conceito & Descrição \\
\hline $\begin{array}{c}\text { Ética } \\
\text { Empresarial } \\
\text { (Business Ethics) }\end{array}$ & $\begin{array}{c}\text { Surgiu das discussões impulsionadas por Milton Friedman, em 1970, ao escrever } \\
\text { um artigo em desfavor da prática da responsabilidade social e foi um campo tomado } \\
\text { pelas discussões filosóficas a cerca da finalidade das organizações, onde } \\
\text { argumentavam que as empresas deveriam sim tratar de questões sociais ao invés de } \\
\text { preocupar-se somente com os lucros; }\end{array}$ \\
\hline $\begin{array}{c}\text { Sociedade } \boldsymbol{e} \\
\text { Negócios }\end{array}$ & $\begin{array}{c}\text { Consolidou-se na década de 1980, no âmbito da revolução causada pelas chamadas } \\
\text { tecnologias da informação. Fundamenta-se numa relação sociopolítica entre } \\
\text { empresa e sociedade, formando uma rede de interesses e relações permeadas por } \\
\text { (Business \& } \\
\text { disputas de poder, por acordos contratuais e pela legitimidade. Dessa forma, a teoria } \\
\text { dos stakeholders torna-se um dos pilares deste campo conceitual, em que a } \\
\text { responsabilidade restrita somente aos acionistas foi substituída pela relação } \\
\text { fiduciária da empresa com as partes interessadas. }\end{array}$ \\
\hline
\end{tabular}




\begin{tabular}{|c|c|}
\hline Gestão de & Surgiu em meados da década de 80, paralelamente ao campo conceitual anterior, no \\
problemas & entanto, baseia-se numa abordagem estratégica, apresentando-se com característica \\
sociais & utilitária e com foco nos conflitos existentes entre empresa e sociedade. Para a \\
(Social Issues & resolução de tal conflito esta abordagem procura dispor de ferramentas de gestão \\
Management) & para maximizar o desempenho ético e moral das organizações. \\
\hline
\end{tabular}

Fonte: Adaptado de Pereira e Filho (2007)

Há presentes na literatura muitos conceitos equivocados a respeito do tema quando configuram a responsabilidade social como um mero instrumento competitivo que serve principalmente para ganhos econômicos frente à construção de uma boa imagem da empresa. A questão da responsabilidade social é, muitas vezes, assumida junto à responsabilidade ambiental responsabilidade socioambiental -, como sendo a resposta natural das empresas ao novo cliente, o "consumidor verde" e ecologicamente correto. A "empresa verde" passou a ser sinônimo de bons negócios com um foco voltado para a geração de lucro e em resposta à pressão do mercado competitivo, não criando uma cultura de responsabilidade propriamente dita, mas mantendo-se limitada às demandas do mercado (TACHIZAWA; TAKESHY, 2008).

O conceito de responsabilidade social é, por vezes, confundido com ações de filantropia, o que caracteriza um conceito equivocado. A responsabilidade social não se detém em promover ações beneficentes, mas sim em adotar um comportamento ético e de total transparência com suas relações de comunicação internas e externas. Dessa forma, uma empresa somente tende a exercer sua responsabilidade social quando "há transferência de seus valores éticos, baseados na sustentabilidade e efetividade de suas ações sociais" (PRIMOLAN, 2004, p. 129).

A Figura 1 a seguir, representa as abordagens da temática social dentro do contexto empresarial. Como pode ser observado há três formas de se trabalhar a vertente social dentro da empresa. A primeira delas refere-se às ações sociais - que são práticas desenvolvidas pela empresa no âmbito social de forma pontual, através de doações, por exemplo, e que se caracterizam, portanto, como filantrópicas onde os resultados são pequenos e não produzem mudança permanente na sociedade. Na próxima abordagem, encontram-se as práticas de investimento social privado onde as empresas investem, apoiam e desenvolvem projetos sociais permanentes, no entanto, mantém o foco exclusivo para um único público: a comunidade. Por fim, a terceira abordagem, a abordagem da responsabilidade social empresarial, centraliza-se na incorporação de valores éticos para mediar suas relações com stakeholders, sejam internos ou externos à empresa, dentro de uma prática de gestão social estratégica (APAS, 2008). 
Figura 1 - Abordagens das questões sociais no âmbito empresarial

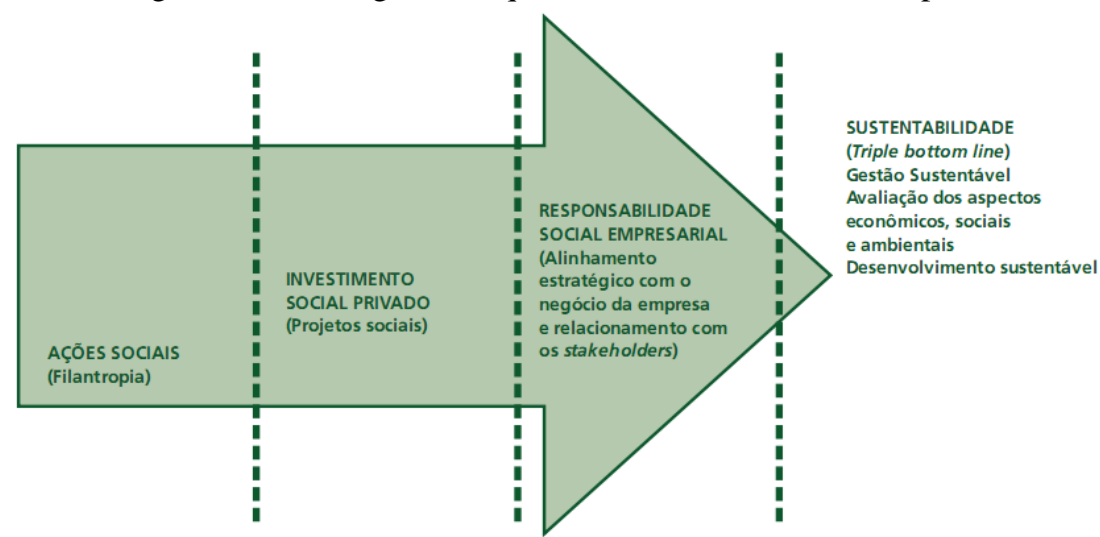

Fonte: Associação APAS (2008)

O conceito de responsabilidade social empresarial deve primar pela ética e estar associado ao relacionamento harmonioso enquanto vivência em seu ambiente interno e externo. E, mais do que isso, deve extrapolar o âmbito do mercado e revestir-se de consciência de seus direitos e deveres fugindo do âmbito exclusivamente econômico onde, "na nova concepção de empresa, esta compreende que a atividade econômica não deve orientar-se somente por uma lógica de resultados, mas também pelo significado que esta adquire na sociedade como um todo" (DIAS, 2008, p.155).

A ética empresarial foge do campo individual da organização e engloba, portanto, "desde as práticas utilizadas pela empresa na venda de produtos ao mercado, a fim de alcançar seus objetivos, até o relacionamento transparente com todos os stakeholders" (ORCHIS; YUNG; MORALES, 2002, p. 57).

Por fim, vale enfatizar que muitos autores têm destacado as vantagens de ser socialmente responsável. Primolan (2004) afirma que estudos demonstraram que o exercício da responsabilidade social pode trazer como benefício à valorização da imagem institucional. Ele destaca também que a responsabilidade social provoca o desenvolvimento de atitudes favoráveis dos consumidores em relação à empresa e o favorecimento aos processos de internacionalização de empresas.

Holme e Watts (2000) declaram que quando há na empresa uma estratégia de RSE coerente, baseada na integridade, valores sólidos e numa abordagem a longo prazo muitos benefícios podem ser vistos, tais como: um melhor alinhamento das metas das empresas com as metas da sociedade, bem como com as metas estabelecidas pelos próprios gerentes dessas empresas; a manutenção da reputação das empresas e a redução de riscos e de custos operacionais.

Portanto, o investimento em RSC é, sobretudo, uma estratégia de aumento do desempenho social e organizacional de longo prazo, que pode refletir também em melhorias de questões econômicas, relacionais e de reputação empresarial. 


\section{O balanço social e indicadores de RSC}

O balanço social é um instrumento de gestão e de informação evidenciando de forma transparente dados de informações econômicas, ambientais e sociais, entre outras informações relativas ao desempenho da empresa dentro de um período pré-estabelecido. Dessa forma, o balanço social é uma maneira de evidenciar ao público a atuação da empresa através de ações sociais desenvolvidas (TOLDO, 2002) e que são expressas de forma quantitativa e qualitativa num relatório que pode ser de periodicidade anual, mensal, etc. Além disso, constitui um instrumento importante, pois torna mais próxima a relação da empresa com a sociedade e com as partes interessadas, tornando pública, informações que outrora se restringia somente ao ambiente empresarial interno.

No Brasil, sentiu-se um despertar de mentalidade para o balanço social através da Associação de Dirigentes Cristãos de Empresas do Brasil (ADCE Brasil), com a publicação da “Carta de Princípios do Dirigente Cristão de Empresas” em 1965, mas foi somente na década de 80 que a Fundação Instituto de Desenvolvimento Empresarial e Social (FIDES) elaborou um modelo de divulgação das atividades sociais das empresas. No entanto, foi a partir dos anos 90 que algumas empresas começaram a divulgação sistemática de suas ações em balanços ou relatórios sociais (TREVISAN, 2002).

Os balanços sociais no Brasil não são expressamente exigidos e não há nenhum modelo que seja de uso obrigatório, embora já exista projeto de lei nesse sentido. Por outro lado, apenas algumas empresas de setores específicos são obrigadas a publicar esta demonstração, como no caso das empresas de energia elétrica, como uma exigência da agência reguladora do setor (DAVID, 2003).

No Brasil, a difusão dessa forma de medição da responsabilidade social empresarial ocorreu em 1997, através da criação do Selo do Balanço Social pelo Instituto Brasileiro de Análises Sociais e Econômicas (Ibase), o que impulsionou muitas empresas a divulgarem os investimentos feitos nos projetos socioculturais através do balanço para obter o selo (ORCHIS; YUNG; MORALES, 2002). A partir de então esse meio de comunicação da responsabilidade social veio sendo amplamente utilizado no meio empresarial e já é, em alguns lugares, requisito legal.

David (2003) traz o exemplo do estado do Rio Grande do Sul, onde após a entrada em vigor da Lei Estadual $n^{\circ} 11.440$ de 18 de Janeiro de 2000, percebeu-se um aumento no interesse das empresas em elaborar e divulgar o balanço social, pois conforme esta lei, quem apresentasse o seu Balanço Social à Assembleia Legislativa do Estado ganharia um selo de responsabilidade social e as três empresas que mais se destacassem receberiam o Troféu Responsabilidade Social. Observou-se também que ano após ano após a entrada em vigor desta Lei, o número de empresas participantes 
aumentava expressivamente, o que indicava também um aumento de interesse dos empresários pela temática social.

Os Indicadores da Responsabilidade Empresarial são questões-chaves que servem de parâmetros para indicar o nível de desenvolvimento das questões sociais de uma empresa e têm sido criados por diversas instituições ao redor do mundo. E como exemplo, tem-se o GRI - Global Reporting Initiative, que serve como um guia para orientar na elaboração de relatórios de sustentabilidade (DELAI; TAKAHASHI, 2008). O GRI foi lançado em 1997 pela Organização Não-Governamental americana Coalition for Environmentally Responsible Economies (CERES) e pelo United Nations Environment Programme e hoje é um dos modelos mais reconhecidos mundialmente.

Aqui no Brasil há destaque para duas organizações que trabalham com a criação de indicadores sociais: o IBASE - Instituto Brasileiro de Análises Sociais e Econômicas e o Instituto Ethos de Responsabilidade Social.

O Instituto Brasileiro de Análises Sociais e Econômicas foi idealizado pelo sociólogo Hebert de Souza, onde no dia 16 de junho de 1997, lançou em parceria com o jornal Gazeta Mercantil e apoio da Comissão de Valores Mobiliários e de diversas empresas, uma campanha nacional de divulgação do balanço social. Dentre os indicadores abordados dentro do modelo do balanço social do Ibase pode-se citar de uma forma geral: receita líquida, folha de pagamento bruta, alimentação, previdência privada, saúde, educação, creche/auxílio-creche, participação nos lucros e resultados, contribuições para a sociedade, programas/projetos externos, entre outros.

Já o Instituto Ethos de Responsabilidade Social é uma organização sem fins lucrativos fundada em 1998 sendo mantida por empresas de diversos setores de atividade que lhe são associadas. Possui diversos projetos, programas e atividades que visam mobilizar, sensibilizar e ajudar as empresas a gerirem seus negócios de forma socialmente responsável. E para fortalecer o movimento pela responsabilidade social no Brasil, o Instituto Ethos concebeu os Indicadores Ethos como um sistema de avaliação do estágio em que se encontram as práticas de responsabilidade social nas empresas.

Os indicadores sociais do instituto podem ser agrupados nas seguintes áreas: Valores, transparência e governança; Público interno; Meio ambiente; Fornecedores; Consumidores e clientes; Comunidade; Governo e sociedade. E conforme o Ethos (2007), “cada tema é dividido em um conjunto de indicadores cuja finalidade é explorar em diferentes perspectivas como a empresa pode melhorar seu desempenho naquele aspecto". Estes temas são constantes num questionário, o qual é respondido pelas empresas constituindo-se como um instrumento de auto-avaliação e aprendizagem, onde a empresa pode identificar os pontos que necessitam ser melhorados. 
Por fim, destaca-se que a utilização de índices ou conjunto de indicadores para medir a sustentabilidade é uma ferramenta relativamente nova e permite auxiliar no processo de tomada de decisão. Delai e Takahashi (2008) propõem um modelo de referência para mensuração da sustentabilidade corporativa baseado na análise de oito formas de mensuração da sustentabilidade baseados em índices ou indicadores e concluem que o uso de indicadores é primordial no processo de gestão, pois o que é medido pode ser gerenciado.

\section{Metodologia da pesquisa}

\subsection{Caracterização da pesquisa}

Quanto ao seu objetivo e procedimento adotado, o presente estudo pode ser caracterizado como uma pesquisa descritiva. A pesquisa descritiva, de acordo com Gil (2006, p. 44), tem como objetivo primordial "a descrição das características de determinada população ou fenômeno ou o estabelecimento de relações entre variáveis [...] utilizando técnicas padronizadas de coleta de dados". Assim, a presente pesquisa satisfaz esta condição por fazer uso de questionário como procedimento adotado para levantamento de dados a respeito de uma população específica supermercados de Natal-RN, a fim de descrever características e comportamentos a ela relacionados sendo tais informações de caráter qualitativo.

O questionário tem a finalidade de investigar, através da utilização de um número relativamente elevado de questões, o conhecimento de opiniões, crenças, sentimentos, práticas, posturas, etc. de uma determinada população. Vale salientar que a maioria das questões constantes no questionário estão organizadas em alternativas de respostas em escala; ditas "escalas sociais", onde há o objetivo de medir a intensidade de opiniões e atitudes de uma forma objetiva e quantificável. A escala social utilizada no questionário foi baseada no modelo de Escala de Likert, que "faz uso de escalas de caráter ordinal de modo a atribuir valores mais altos a atitudes mais favoráveis e a menos favorável o valor mais baixo" (GIL, 2006, p. 147).

A pesquisa utilizou um universo de aplicação dos questionários quatro lojas de supermercados atuantes no município de Natal-RN, que, para fins de preservação de sua imagem, serão chamadas aqui de: Supermercado A, Supermercado B, Supermercado C e Supermercado D.

\subsection{Instrumento de coleta de dados}

Para a coleta de dados a pesquisa utilizou-se de um questionário dividido em seis grupos de variáveis analíticas, com um total de 40 variáveis destinadas a avaliar os aspectos da responsabilidade social empresarial para o setor de supermercados em Natal-RN, além de uma caracterização socioeconômica das empresas e dos respondentes. 
As variáveis do instrumento de coleta de dados foram desenvolvidas com base nos Indicadores Ethos de RSE (2008), sendo adaptadas conforme as características do setor de varejo.

Baseado no critério estrutural utilizado por Delai e Takahashi (2008), que declaram que a dimensão social relaciona-se com diversos stakeholders, é necessário se fazer uma delimitação clara das dimensões a serem trabalhadas dentro do contexto da responsabilidade social. Dessa forma, foram estabelecidas quatro seções onde foram avaliadas variáveis da responsabilidade social para três grandes grupos de stakeholders: o público interno, o público externo e o meio ambiente, englobando-se também questões relacionadas ao perfil da empresa e do gestor respondente, conforme descrição a seguir.

\section{- Grupo I - indicadores de RSC para o ambiente interno (RSC-I)}

Essa seção objetivou avaliar as práticas de responsabilidade social adotadas no ambiente empresarial (interno), bem como questões que permitem observar o nível de importância atribuída às ações sociais internas, o nível de maturidade e a forma de realização destas práticas na empresa. Foram definidas aqui 15 variáveis, sendo elas: Forma de difusão de valores e princípios éticos internamente (RSC-I-1); Frequência de difusão de valores e princípios éticos internamente (RSC-I2); Forma com que a RSC é trabalhada no ambiente organizacional (RSC-I-3); Forma de envolvimento dos empregados no processo de gestão (RSC-I-4); Compromisso com o futuro das crianças (RSC-I-5); Combate a todas as formas de descriminação e respeito à diversidade social e equidade racial (RSC-I-6); Atitude com relação à política de remuneração benefícios e carreiras (RSC-I-7); Atitude com relação às condições de trabalho, saúde e segurança (RSC-I-8). Também, neste grupo de variáveis foram analisadas as ações/práticas de RSC implementadas no ambiente interno, a saber: Plano de saúde familiar ou outro tipo de auxílio médico aos seus funcionários (RSC-I-9-a); auxílio alimentação ou cesta básica aos seus funcionários (RSC-I-9-b); Programas de combate ao tabagismo e ao alcoolismo (RSC-I-9-c); Orientação quanto às DST's com seus funcionários (RSC-I-9-d); Programa de combate a LER (RSC-I-9-e); Programa de atividade física com seus funcionários (por exemplo, ginástica laboral) (RSC-I-9-f); Programa de valorização do funcionário objetivando a manutenção deste na empresa e evitando uma maior rotatividade (RSC-I9 -g).

\section{- Grupo II - indicadores de RSC para o ambiente externo (RSC-E)}

Esse grupo de variáveis analíticas abordou os indicadores da RSC para o ambiente externo, com um total de 14 variáveis, a saber: Forma de difusão de valores e princípios éticos externamente (RSC-E-1); Frequência de difusão de valores e princípios éticos externamente (RSC-E-2); Difusão de relatórios/balanços sociais (RSC-E-3); Existência de critérios de seleção e avaliação de fornecedores (RSC-E-4); Existência de apoio e desenvolvimento de fornecedores (RSC-E-5); 
Atitude com relação à interferência e impactos causados na vida da comunidade (RSC-E-6); Atitude com relação ao relacionamento estabelecido com organizações e grupos locais (RSC-E-7); Atitude com relação ao seu papel na construção da cidadania (RSC-E-8). Finalmente, em relação à implementação de ações/práticas de RSC no ambiente externo, foi avaliado: Existência de Treinamento e Qualificação de Funcionários (cursos, seminários, programas e projetos internos) (RSC-E-9-a); Realização de Projetos com a Comunidade (RSC-E-9-b); Auxílio à projetos sociais de ONG's e outras entidades (RSC-E-9-c); Marketing Social através de propagandas eletrônicas e impressas (RSC-E-9-d); Apoio ao Desenvolvimento de Fornecedores (RSC-E-9-e); Realização de Ações e Projetos Voltados para os Clientes (RSC-E-9-f). Para estes variáveis, também foi verificado o investimento realizado.

\section{- Grupo III - indicadores de RSC para o meio ambiente (RSC-MA)}

Essa seção visou avaliar as formas de interferência da empresa sob o meio ambiente e as praticas/ações desenvolvidas pela empresa. Assim, as varáveis componentes foram: Atitude com relação à responsabilidade sobre os impactos ambientais da atividade (RSC-MA-1); Atitude com relação à educação e conscientização ambiental da população (RSC-MA-2); Atitude com relação ao gerenciamento dos impactos ambientais de seus processos, produtos e serviços (RSC-MA-3). Com relação, as ações/práticas e projetos de caráter ambiental desenvolvido pela empresa, foram considerados: Existência de Medidas de Redução do Consumo e/ou Uso de Fontes Renováveis de Energia (RSC-MA-4-a); Existência de Medidas de Redução do Consumo de Água (RSC-MA-4-b); Possui Programas de Redução da Geração de Resíduos Sólidos (RSC-MA-4-c); Existência de Programa de Coleta Seletiva de materiais recicláveis (RSC-MA-4-d); Existência de Programa de Postos de Coleta de óleo de cozinha (RSC-MA-4-e); Existência de Programa de Coleta de Pilhas e Baterias (RSC-MA-4-f); Existência de Estação de Tratamento de Efluentes (RSC-MA-4-g); Existência de Estimulo ao Uso de Sacolas Retornáveis (Ecobags) (RSC-MA-4-h); Existência de programa de Educação Ambiental para a comunidade (RSC-MA-4-i). Para estes variáveis, também foi verificado o investimento realizado.

\section{- Grupo IV - caracterização da empresa e respondente perfil}

Para a caracterização da empresa foi analisado o perfil socioeconômico da empresa, incluindo porte, tempo de atuação da empresa no mercado, número de funcionários, número médio de clientes, faturamento anual, número médio de fornecedores, área total construída, endereço e contatos.

Já para o perfil do respondente foi analisado o sexo, faixa etária, nível de escolaridade, tempo de atuação na empresa, renda familiar. 
Em relação à escala de resposta, o questionário foi constituído de questões fechadas e de múltipla escolha e foram elaboradas a fim de criar uma escala evolutiva de parâmetros que revela o nível de maturidade das ações de responsabilidade social da empresa para cada variável respondida. Para as variáveis de atitude geral, foi adotado como escala de respostas cinco alternativas que refletiam níveis de profundidade para as atitudes gerais e ações/práticas de $\operatorname{RSC}(0,1,2,3$ e 4$)$ (Quadro 2). Já para as variáveis para as mensurar as ações/práticas, no caso as variáveis RSC-I-9 (a,b,c,d,e,f,g), RSC-E-9 (a,b,c,d,e,f) e RSC-MA-4(a,b,c,d,e,f,g,h) foi adotado o Quadro 3.

O Apêndice A apresenta todas as variáveis e escalas de resposta.

\subsection{Descrição do índice de RSC para supermercados}

Para comparar o desempenho das empresas avaliadas sobre às questões de RSC optou-se por criar um índice de classificação das empresas de acordo com as respostas dadas no questionário. Para tanto foram avaliadas as respostas dos gestores de cada supermercado para as variáveis contidas nos grupos I (RSC-I), II (RSC-E) e III (RSC-MA) que tratam, respectivamente, dos indicadores para o público interno, público externo e os indicadores da responsabilidade social para o meio ambiente.

Quadro 2 - Descrição dos níveis de maturidade das atitudes gerais de RSC.

\begin{tabular}{|c|c|c|}
\hline $\begin{array}{c}\text { Níveis de } \\
\text { Maturidade } \\
\text { (Score) }\end{array}$ & Classificação & Descrição \\
\hline 0 & Sem Opinião & $\begin{array}{c}\text { O valor } 0 \text { (zero) é atribuído às questões em que há ausência de opinião } \\
\text { do gestor; }\end{array}$ \\
\hline 1 & Estágio Iniciante & $\begin{array}{l}\text { O valor } 1 \text { (um) é atribuído às questões consideradas sem importância } \\
\text { ou de aplicabilidade baixa; }\end{array}$ \\
\hline 2 & Estágio Defensivo & $\begin{array}{c}\mathrm{O} \text { valor } 2 \text { (dois) é atribuído às questões consideradas pouco importantes } \\
\text { ou onde o nível de aplicabilidade é mediano; }\end{array}$ \\
\hline 3 & Estágio Intermediário & $\begin{array}{c}\text { O valor } 3 \text { (três) é atribuído às questões consideradas importantes ou } \\
\text { onde o nível de aplicabilidade é satisfatório; }\end{array}$ \\
\hline 4 & Estágio Avançado & $\begin{array}{l}\text { O valor } 4 \text { (quatro) é atribuído às questões consideradas de extrema } \\
\text { importância ou onde o nível de aplicabilidade é máximo. }\end{array}$ \\
\hline
\end{tabular}

\begin{tabular}{|c|c|c|}
\hline Pontuação & Nível de Maturidade & Descrição \\
\hline 0 & $\begin{array}{l}\text { Sem Opinião/ Ação } \\
\text { Não Implementada }\end{array}$ & $\begin{array}{l}\text { O valor } 0 \text { (zero) é atribuído quando há ausência de opinião do gestor } \\
\text { ou quando a ação não encontra-se implementada; }\end{array}$ \\
\hline 1 & Estudando Viabilidade & $\begin{array}{l}\text { O valor } 1 \text { (um) é atribuído quando a ação encontra-se na fase de } \\
\text { avaliação da viabilidade de aplicação; }\end{array}$ \\
\hline 2 & $\begin{array}{l}\text { Em processo de } \\
\text { Implementação }\end{array}$ & $\begin{array}{c}\text { O valor } 2 \text { (dois) é atribuído quando a ação encontra-se em processo } \\
\text { de implementação; }\end{array}$ \\
\hline 3 & Ação Implementada & $\begin{array}{c}\text { O valor } 3 \text { (três) é atribuído à ação que já encontra-se implementada } \\
\text { na empresa. }\end{array}$ \\
\hline
\end{tabular}

A composição do índice foi feita com o somatório da pontuação que as empresas atingiram em cada grupo (Equação 01). Assim, a pontuação alcançada em cada um destes grupos refletirá o nível de maturidade da empresa em relação à RSC.

$$
\mathrm{IGS}=\mathrm{PG} \mathrm{I}+\mathrm{PG} \text { II + PG III }
$$


Onde:

IGS= Índice Geral do Supermercado

PG I = Pontos Grupo RSC-I

PG II = Pontos Grupo RSC-E

PG III = Pontos Grupo RSC-MA

Por fim, a partir do índice gerado para cada supermercado será possível verificar o nível de maturidade das práticas de responsabilidade social corporativa e comparar a situação entre os supermercados de forma qualitativa.

\section{Análise e discussão dos resultados}

\subsection{Perfil geral das empresas e gestores entrevistados}

As empresas entrevistadas caracterizam-se por representantes de redes de supermercados de atuação local e nacional. Sendo, portanto, dois representantes de supermercados com atuação estritamente local (A e B) e dois representantes de supermercados de atuação nacional (C e D). O perfil socioeconômico das empresas entrevistadas é apresentado na Tabela 1.

Tabela 1 - Perfil das empresas entrevistadas

\begin{tabular}{c|c|c|c|c|c|c}
\hline Empresas & Porte & $\begin{array}{c}\text { Tempo de } \\
\text { Atuação } \\
(\text { anos) }\end{array}$ & $\begin{array}{c}\mathbf{N}^{\mathbf{0}} \text { de } \\
\text { Funcionários }\end{array}$ & $\begin{array}{c}\mathbf{N}^{\mathbf{o}} \text { Médio de } \\
\text { Fornecedores }\end{array}$ & $\begin{array}{c}\mathbf{N}^{\mathbf{o}} \text { Médio de } \\
\text { Clientes }\end{array}$ & $\begin{array}{c}\text { Área } \\
\text { Construída } \\
\left(\mathbf{m}^{\mathbf{2}} \mathbf{)}\right.\end{array}$ \\
\hline A & Médio & 1 & 350 & 375 & 80.000 & 3000 a 5000 \\
\hline $\mathrm{B}^{*}$ & Grande & 37 & 2257 & - & - & - \\
\hline C & Médio & 9 & 399 & - & 3.000 & $>5000$ \\
\hline D & Médio & 13 & 350 & - & 120.000 & $>5000$ \\
\hline
\end{tabular}

*Os dados especificados para este supermercado não representam a realidade de uma loja específica, mas refere-se à rede que é composta por várias lojas espalhadas no município.

Destaca-se que o Supermercado B está caracterizado como um estabelecimento de grande porte devido o seu número elevado de funcionários. No entanto, os dados não especificam a realidade de uma loja, mas referem-se à rede como um todo, representada por sete lojas. Dessa forma, dividindo-se, por exemplo, o $\mathrm{n}^{\mathrm{o}}$ de funcionários do supermercado B (2257) pelo número de lojas da rede (sete), obtém-se um valor médio de 322 funcionários por loja. Dessa forma, é possível considerar o porte do Supermercado B como sendo médio também.

Quanto ao perfil dos entrevistados, o representante do Supermercado D é o que atua na empresa há mais tempo, com 13 anos de experiência, seguido pelo gestor do Supermercado B, que ocupa o cargo de Assistente Social, atua há seis anos na empresa. O gestor representante do Supermercado A que ocupa o cargo de Gerente de Marketing e Financeiro e afirmou estar ocupando o cargo na empresa há dois anos e o gestor representante do Supermercado $C$, que ocupa o cargo de Consultor de Capital Humano, encontra-se na empresa atuando somente há um mês. Dessa forma, pode-se inferir que os níveis de conhecimento a respeito da política e das práticas realizadas pela empresa podem ser expressos de forma diferenciada entre os entrevistados, visto que cada um 
responde conforme ao seu tempo de experiência e atuação na empresa. Isso, entretanto, não é regra e dependerá também do grau de conhecimento e envolvimento do gestor com as questões de cunho sócioambiental. Além disso, os cargos ocupados por cada um deles exercem influência nas opiniões a respeito dos questionamentos realizados durante a entrevista, visto que cada um pode estar tomando por base as atividades realizadas em seu setor específico.

Além disso, verificou-se ainda que as formas com que a RSC é trabalhada dentro do ambiente empresarial foram bastante diversificadas. O supermercado A declarou que não trabalha de forma direta questões que envolve RSC com seu público interno, o supermercado B declara que há um setor específico para trabalhar as questões de RSC de forma sistemática e periódica, enquanto que o supermercado C trabalha a RSC de forma transversal e contínua dentro da empresa, sob orientação de um profissional especializado na área e dentro de um setor específico. Já o supermercado D afirma que possui um profissional responsável pelas questões de RSC mas não é especialista na área e atua de forma pontual.

\subsection{Diagnóstico dos aspectos de RSC nas empresas entrevistadas}

\subsubsection{Indicadores da RSC para o ambiente interno}

A Tabela 2 apresenta os resultados para os indicadores da RSC para o ambiente interno. É possivel observar que em relação às variáveis relacionadas às atitudes gerais de RSC para o ambiente interno, houve um comportamento homogêneo para as variáveis RSC-I-1, RSC-I-2 e RSC-I-7, estando os supermercados B, C e D em um nível avançado em termos de divulgação de princípios éticos (RSC-I-1 e RSC-I-2) e relação à política de remuneração benefícios e carreiras (RSC-I-7). Por outro lado, observa-se que o Supermercado A, que possui um número médio de 80000 clientes, 375, fornecedores e 350 funcionários, apresentou um posicionamento considerado como inicial para as variáveis RSC-I-1 e RSC-I-2 e Intermediário para RSC-I-7. Em adição, nota-se que o supermercado A apresentou um posicionamento entre iniciante e defensivo entre as variáveis

RSC-I-1 e RSC-I-8, enquanto que o Supermercado $C$ apresentou os melhores resultados, ficando posicionado com maior tendência no estágio avançado em termo de RSC para o ambiente interno.

Também foi possível observar uma maior discrepância no posicionamento das empresas nas variáveis RSC-I-3 e RSC-I-4. Destaca-se também que sobre o envolvimento dos empregados no processo de gestão das empresas (RSC-I-4), as lojas de atuação nacional apresentam um maior nível de maturidade, envolvendo os seus empregados na gestão através de um processo estruturado de discussão e análise de riscos e oportunidades sobre questões econômico-financeira da empresa ou através da participação das decisões estratégicas da empresa, enquanto que as empresas de atuação local não indicaram importância para esta questão, onde uma não opinou a respeito (supermercado A) e a outra declara que somente dispõe de informações sobre a empresa e treina os funcionários 
para melhor conhecê-las, sem haver participação dos mesmos nas reuniões e decisões estratégicas da empresa.

Tabela 02 - Nível de maturidade e índice parcial das ações de RSC com o público interno (PGI)

\begin{tabular}{|c|c|c|c|c|}
\hline \multirow{3}{*}{ Variável* } & \multicolumn{4}{|c|}{ Empresas } \\
\hline & \multicolumn{2}{|c|}{ Local } & \multicolumn{2}{|c|}{ Nacional } \\
\hline & $\mathbf{A}$ & B & $\mathbf{C}$ & D \\
\hline RSC-I-1 & 1 & 4 & 4 & 4 \\
\hline RSC-I-2 & 1 & 4 & 4 & 4 \\
\hline RSC-I-3 & 1 & 3 & 4 & 2 \\
\hline RSC-I-4 & 0 & 1 & 3 & 4 \\
\hline RSC-I-5 & 2 & 3 & 3 & 2 \\
\hline RSC-I-6 & 2 & 2 & 4 & 3 \\
\hline RSC-I-7 & 3 & 4 & 4 & 4 \\
\hline RSC-I-8 & 2 & 3 & 4 & 2 \\
\hline RSC-I-9-a & 3 & 3 & 3 & 3 \\
\hline RSC-I-9-b & 3 & 0 & 0 & 3 \\
\hline RSC-I-9-c & 1 & 3 & 3 & 1 \\
\hline RSC-I-9-d & 3 & 3 & 3 & 3 \\
\hline RSC-I-9-e & 2 & 3 & 3 & 3 \\
\hline RSC-I-9-f & 2 & 3 & 2 & 3 \\
\hline RSC-I-9-g & 2 & 3 & 3 & 3 \\
\hline Soma Parcial & 28 & 42 & 47 & 44 \\
\hline
\end{tabular}

* ver Quadro 2 para RSC-I-1 a RSC-I-1 e Quadro 3 para RSC-I-9-a a RSC-I-9-g

Já em relação às ações e práticas de RSC no ambiente interno adotadas pelas empresas (RSC-I-9), o Supermercado D apresentou seis ações implementadas e uma ação em estudo de viabilidade (Programas de combate ao tabagismo e ao alcoolismo - RSC-I-9-c). O segundo melhor desempenho foi do Supermercado B, com seis ações implementadas.

É importante notar que todos os supermercados analisados possuem ações relacionadas à adoção de plano de saúde familiar ou outro tipo de auxílio médico aos seus funcionários (RSC-I-9a) e Orientação quanto às DST's com seus funcionários (RSC-I-9-d).

O programa de combate a LER (RSC-I-9-e) e programa de valorização do funcionário objetivando a manutenção deste na empresa e evitando uma maior rotatividade (RSC-I-9-g) estão implementados ou em processo de implementação nos supermercados investigados. Por outro lado, o auxílio alimentação ou cesta básica aos seus funcionários (RSC-I-9-b) está implementada apenas pelos supermercados A e D.

\subsubsection{Indicadores da RSC para o ambiente externo}

A Tabela 3 apresenta os resultados para as variaveis do grupo de indicadores de RSC para o ambiente externo. Inicialmente, em relação à forma de comunicação de ações de RSC com o ambiente externo, analisada através das variaveis RSC-E-1 - Forma de difusão de valores e princípios éticos externamente, RSC-E-2 - Frequência de difusão de valores e princípios éticos externamente e RSC-E-3 - Difusão de relatórios/balanços sociais, pode ser constatado que o Supermercado $C$ apresentou uma maior coerência nas respostas, já que os valores e princípios 
éticos da empresa é disseminado continuamente por todos os funcionários através da incorporação voluntária e da influencia do exemplo de seus coordenadores setoriais, além de ser divulgados periodicamente no ambiente externo e seu relatório/balanço social é adotado com publicação periódica. Observa-se também que os supermercados locais divulgam seus princípios permanentemente, todavia não faz uso do balanço social de forma sistemática. Em adição, o Supermercado $D$ divulga seus princípios em eventos pontuais e não faz uso de balanço social. Assim, percebe-se que em relação à divulgação do balanço social, uma falta de compromisso da maioria dos supermercados entrevistados em quantificar e publicar atualizações periódicas de dados sobre os aspectos econômicos, sociais e ambientais da empresa.

Tabela 03 - Nível de maturidade e índice parcial das ações de RSC com o público externo (PGII)

\begin{tabular}{|c|c|c|c|c|}
\hline \multirow{3}{*}{ Variável* } & \multicolumn{4}{|c|}{ Empresas } \\
\hline & \multicolumn{2}{|c|}{ Local } & \multicolumn{2}{|c|}{ Nacional } \\
\hline & $\mathbf{A}$ & B & $\mathbf{C}$ & D \\
\hline RSC-E-1 & 3 & 2 & 4 & 4 \\
\hline RSC-E-2 & 4 & 4 & 3 & 2 \\
\hline RSC-E-3 & 3 & 2 & 4 & 1 \\
\hline RSC-E-4 & 4 & 2 & 3 & 3 \\
\hline RSC-E-5 & 1 & 1 & 2 & 3 \\
\hline RSC-E-6 & 2 & 4 & 4 & 2 \\
\hline RSC-E-7 & 2 & 4 & 3 & 1 \\
\hline RSC-E-8 & 1 & 1 & 0 & 1 \\
\hline RSC-I-9-a & 3 & 3 & 3 & 3 \\
\hline RSC-I-9-b & 3 & 3 & 3 & 1 \\
\hline RSC-I-9-c & 3 & 3 & 3 & 3 \\
\hline RSC-I-9-d & 0 & 3 & 3 & 3 \\
\hline RSC-I-9-e & 2 & 3 & 3 & 3 \\
\hline RSC-I-9-f & 2 & 3 & 3 & 3 \\
\hline Soma Parcial & 33 & 38 & 41 & 33 \\
\hline
\end{tabular}

Segundo Kuhndt (2004), a escolha e desenvolvimento dos fornecedores podem ser direcionados para questão da sustentabilidade e RSC. Assim, foi analisado a adoção de critérios de seleção (RSC-E-4), e o relacionamento e apoio com os fornecedores (RSC-E-5) e a adoção de ações práticas de apoio e desenvolvimento (RSC-E-9-e). Pelos resultados, os supermercados com rede nacional, C e D, tiverem uma melhor atitude adotando critérios de RSC para seleção e oferecem treinamentos para os fornecedores. De forma geral, fica constatado que quanto ao relacionamento e apoio ao desenvolvimento de fornecedores as empresas nacionais demonstram uma maior preocupação e interesse em contribuir com seus fornecedores, buscando promover atividades conjuntas de treinamento visando contribuir para a melhoria gerencial de fornecedores, já as empresas locais apenas negociam com tranparência e estebelece relações contratuais independente do porte do fornecedor.

No que diz respeito a variavel RSC-E-6 - Atitude com relação à interferência e impactos causados na vida da comunidade, os supermercados B e C, se posicionaram em um estagio 
avançado, se antecipando às demandas da comunidade informando-as sobre atuais e futuros planos e impactos de sua atividade, envolvendo a comunidade na resolução dos problemas e mantendo comitês permanentes com a participação da comunidade a fim de analisar e monitorar os impactos de sua atividade.

Observa-se ainda que a variável RSC-E-7 - Atitude com relação ao relacionamento estabelecido com organizações e grupos locais, apresentou resultados mais heterogêneos e na variável RSC-E-8 - Atitude com relação ao seu papel na construção da cidadania, os supermercados se posicionaram no estagio iniciante.

Já em relação as variaveis que mensuraram as ações/práticas de RSC no ambiente externo, nota-se que a existência de treinamento e qualificação de funcionários (cursos, seminários, programas e projetos internos) (RSC-E-9-a) e o auxílio aos projetos sociais de ONG's e outras entidades (RSC-E-9-c) são ações implementadas em todos os supermercados. Em adição, observase os supermercados avaliados estão com as ações implementadas ou em processo de implementação.

De forma geral, considerando as variáveis RSC-E-1 a RSC-E-8, os supermercados ficaram situados entre os níveis 2 (defensivo) e 3 (intermediário), com destaque para os supermercados B e C. Esses supermercados também se destacaram nas variáveis que mensuraram as ações/praticas implementadas, que eles têm todas as medidas implementadas. Mais uma vez, o supermercado C foi o melhor pontuado no somatório geral.

\subsubsection{Indicadores da RSC para o meio ambiente}

A Tabela 4 apresentas os resultados para os indicadores de RSC para o meio ambiente. É possivel, observar que aqanto a responsabilidade sobre os impactos ambientais resultantes da atividade da empresa (RSC-MA-1) maioria dos supermercados ainda centralizam-se no cumprimento aos parâmetros e requisitos legais ou possui programas internos de melhoramento ambiental (empresas A, B e D). Somente o Supermercado $C$, declara que ao desenvolver seus negócios considera os princípios da sustentabilidade ambiental e as oportunidades relacionadas. Sobre o gerenciamento de impactos ambientais causados por seus processos e produtos ou serviços (RSC-MA-3) a maioria dos supermercados (A, B e C) além de cumprir com a legislação, conhecem e desenvolvem ações de prevenção de impactos e realizam regularmente atividades de controle e monitoramento. Já o supermercado D, um passo a frente, cumpre com essas atividades e declara que possui sistema de gestão ambiental padronizado e inclui a identificação de riscos, plano de ação, alocação de recursos, treinamento de empregados e auditoria. 
Tabela 04 - Nível de maturidade e índice parcial das ações de RSC e Meio Ambiente (PGIII)

\begin{tabular}{|c|c|c|c|c|}
\hline \multirow{3}{*}{ Variável } & \multicolumn{4}{|c|}{ Empresas } \\
\hline & \multicolumn{2}{|c|}{ Local } & \multicolumn{2}{|c|}{ Nacional } \\
\hline & $\mathbf{A}$ & B & $\mathbf{C}$ & D \\
\hline RSC-MA-1 & 1 & 2 & 4 & 1 \\
\hline RSC-MA-2 & 2 & 3 & 3 & 2 \\
\hline RSC-MA-3 & 2 & 2 & 2 & 3 \\
\hline RSC-MA-5-a & 3 & 3 & 3 & 3 \\
\hline RSC-MA-5-b & 3 & 0 & 3 & 3 \\
\hline RSC-MA-5-c & 1 & 3 & 3 & 1 \\
\hline RSC-MA-5-d & 0 & 1 & 3 & 2 \\
\hline RSC-MA-5-e & 3 & 1 & 3 & 2 \\
\hline RSC-MA-5-f & 3 & 1 & 3 & 3 \\
\hline RSC-MA-5-g & 1 & 0 & 0 & 3 \\
\hline RSC-MA-5-h & 2 & 3 & 3 & 3 \\
\hline RSC-MA-5-i & 0 & 3 & 0 & 0 \\
\hline Soma Parcial & 22 & 23 & 32 & 29 \\
\hline
\end{tabular}

As ações de educação ambiental desenvolvidas pelas empresas (RSC-MA-2) são de modo geral dispersas, geralmente atuando através de um programa interno divulgando informações e estimulando discussões com o público interno ou através da realização de campanhas de educação ambiental destinadas aos clientes, fornecedores ou comunidade do entorno.

De forma geral, considerando as três primeiras variáveis analisadas, as empresas investigadas estão alocadas entre os estágios inicial e reativo. Agora, considerando as variáveis de mensuração das ações práticas de RSC desenvolvidas pelas empresas com foco no meio ambiente, vale a pena destacar que a redução do consumo de energia (RSC-MA-4-a) está implementada por todas as organizações. Enfatiza-se que o custo energético para este tipo de organização é bastante significativo, principalmente pelo consumo demandado para a conservação e preparos dos alimentos, além a refrigeração das lojas. Outra ação compartilhada por quase todas as empresas avaliadas foi o programa de coleta de pilhas e baterias, sendo uma ação ausente somente no supermercado $B$. Essa é uma boa iniciativa, entretanto, esta ação já se constitui uma obrigação legal, conforme dispõe a Resolução do CONAMA n 257 de 1999 em seu Art. $3^{\circ}$, que diz que os estabelecimentos que comercializam pilhas e baterias ficam obrigados a receber dos usuários/clientes as unidades após uso. Destaca-se também a coleta de óleo de cozinha por parte das empresas A e C, e em processo de implementação no supermercado D.

Por outro lado, os supermercados investigados tiveram um pior posicionamento no desenvolvimento de programa de Educação Ambiental para a comunidade (RSC-MA-4-i). Apenas o Supermercado B tinha este programa implementado, os demais não tinha nenhum procedimento implementado.

\section{3. Índice geral de $\mathrm{RSC}$}

O índice geral de RSC das empresas foi obtido através dos sumatório dos valores alcançados para o conjunto de indicadores discutidos nos topicos anteriores. Foi constatado que de forma geral, 
o Supermercado $C$ obteve a melhor pontuação entre os supermercados atingindo $85 \%$ da pontuação maxima total, e estando melhor posicionado nos tres grupos de variaveis. Destaca-se que os supermercados ficaram melhor posicionados nos grupos de RCS interna, seguido de RSC Externo. O grupo de variaveis para o meio ambiente apresentou um pior desempenho principalmente para os supermercados locais.

Tabela 05 - Índice comparativo de RSC dos supermercados

\begin{tabular}{|c|c|c|c|c|c|}
\hline \multirow{3}{*}{ Grupos } & \multicolumn{5}{|c|}{ Empresas } \\
\hline & \multicolumn{2}{|c|}{ Local } & \multicolumn{2}{|c|}{ Nacional } & \multirow{2}{*}{$\begin{array}{c}\text { Pontuação } \\
\text { Máxima Possível }\end{array}$} \\
\hline & $\mathbf{A}$ & B & $\mathbf{C}$ & D & \\
\hline PGI & 28 & 42 & 47 & 44 & 53 \\
\hline PGII & 33 & 38 & 41 & 33 & 50 \\
\hline PGIII & 22 & 23 & 32 & 29 & 39 \\
\hline Índice Total & 83 & 103 & 120 & 106 & 142 \\
\hline
\end{tabular}

No entanto, vale ressaltar uma notória diferença observada no PGI, onde o Supermercado A, encontra-se com um valor inferior, quando comparado aos demais, para a questão da relação com o público interno. Isso pode ser explicado pela natureza na atuação do gestor entrevistado. Este atua na empresa como gerente de marketing e financeiro, além de sua formação ser na área de economia, tais características pode influenciar diretamente na natureza e importância atribuída às questões de valorização de recursos humanos. Isso é confirmado por Parente e Terepins (2006, p. 14), declarando que "as empresas com gestores na área de RH apresentam ações significativas em benefício do seu público interno", o que não é o caso do gestor desta empresa.

Outra diferença significante está presente no PGIII, onde se observou que o desempenho das empresas locais está aquém daquele observado para as empresas com atuação nacional, isso implica dizer que há na gestão das empresas nacionais, conforme explica Parente e Terepins (2006), uma influência na transmissão dos valores da matriz para as suas filiais. Nesse caso, as empresas de atuação nacional investigadas possuem matrizes de capital multinacional e isso pode influenciar diretamente no padrão de atuação destas empresas até mesmo a nível local. Entretanto, vale salientar que para as partes que tratam do público interno e externo esse padrão não é observado.

Sobre os indicadores da RSC para o ambiente interno (Grupo II - PI) observa-se uma forte relação entre os índices dos Supermercados $B, C$ e $D$, ou seja, eles compartilham de um desempenho muito semelhante no que diz respeito aos indicadores do ambiente interno. Em contrapartida, o Supermercado A encontra-se num nível mais inferior quando comparado aos demais supermercados. Isso pode ser verificado quando se avalia a forma, frequência e importância atribuída à disseminação de valores e princípios éticos dentro das empresas. Os supermercados B, C e D apresentam praticamente a mesma conduta com relação à este quesito já bem desenvolvido, no entanto, o supermercado A apresentou um cenário muito alarmante, não apresentando sequer uma lista de valores e princípios éticos e nem processo de difusão estruturado com seus funcionários. 
Conforme orientações da APAS (2008), a declaração de princípios e valores éticos é uma importante referência para a gestão sustentável dos negócios. Entretanto, nem sempre a existência de um Código de Conduta garante a incorporação de responsabilidade social. Ou seja, a existência do Código de Ética em si não garante a incorporação de valores e princípios éticos, sendo necessário se trabalhar de forma mais direta uma metodologia que garanta a inserção desses valores na cultura da organização de forma contínua, fazendo com que esses valores saiam efetivamente do papel.

Um importante indicador da RSC para o ambiente interno é o envolvimento dos funcionários dentro do processo de gestão. E para as empresas entrevistadas este quesito apresentou bastante heterogêneo. O Supermercado A preferiu não opinar sobre o assunto, revelando o desconhecimento da política adotada pela alta administração ou então prefere não se comprometer com a resposta. A resposta dada pelo Supermercado B não demonstra inserção da opinião de funcionários no processo de gestão, pelo contrário, a empresa somente dispõe de informações sobre a empresa e treina seus empregados para conhecê-las melhor, sem fazer qualquer interferência nessas questões. A realidade do Supermercado $C$ é um pouco melhor, pois, conforme resposta do gestor, além de dispor destas informações para o funcionário ainda faz uso de um processo estruturado de discussão e análise de riscos e oportunidades com seus empregados sobre questões econômico-financeiras, o que, de certa forma, não efetiva a participação do funcionário no processo de gestão com poder de opinião. O melhor desempenho foi observado nas práticas do Supermercado $D$ pois realiza as ações desenvolvidas pelos demais supermercados e ainda inclui a participação ativa dos funcionários nas decisões estratégicas da empresa. De uma forma geral, destaca-se uma melhor atuação para este quesito daquelas empresas que atuam em todo o território nacional.

Em pesquisa realizada por Furtado e Pena (2007), que buscou avaliar a RSC com o público interno a partir da percepção de funcionários de uma empresa, eles destacaram que "o processo aberto e transparente do planejamento estratégico realizado pela empresa é um ponto forte no que diz respeito à gestão participativa" (FURTADO; PENA, 2007, p.8). Assim, tal afirmativa confirma o efeito positivo da gestão participativa de funcionários da empresa e serve como exemplo de incentivo para as empresas avaliadas que apresentaram um baixo nível de maturidade quanto a esta prática participativa na gestão.

Sobre os indicadores do ambiente externo foram abordadas questões que trataram basicamente da comunicação da empresa com o público externo, da relação da empresa com fornecedores e da relação da empresa com a comunidade. Assim sendo, praticamente todos os supermercados consideraram extremamente importante a existência de uma boa comunicação e relacionamento com stakeholders, exceto a empresa B que considerou tal ação importante. Sobre a 
qualidade no serviço de atendimento ao consumidor os Supermercados $A$ e $D$ afirmaram que registram e resolvem as demandas do consumidor e ainda possuem procedimentos de busca das causas do problema e as utiliza no processo de melhoria da qualidade de produtos e serviços. Os Supermercados $B$ e $C$ declararam que buscam sempre a melhoria contínua no processo de atendimento ao consumidor com prioridade no diálogo e engajamento das partes interessadas.

Sobre relacionamento com fornecedores a empresa A, uma das representantes locais, possui normas de seleção e avaliação de fornecedores que contemplam critérios de cumprimento à legislação trabalhista, previdenciária e fiscal, incorpora critérios de responsabilidade social e ainda realiza o monitoramento periódico destes critérios. O Supermercado A declara também que negocia com transparência e estabelece relações contratuais independente do porte do fornecedor. A empresa B, a outra representante local, foi a que apresentou um estágio mais básico de relacionamento com fornecedores, apenas possui normas de seleção e avaliação baseadas no cumprimento à legislação e negocia com transparência com seus fornecedores. As empresas C e D, representantes nacionais apresentaram, apresentaram a mesma postura quanto à este critério: cumprem o que determina a legislação trabalhista, previdenciária e fiscal e buscam incorporar critérios de responsabilidade social nas suas normas de seleção e avaliação de fornecedores. E para fortalecer o relacionamento com fornecedores elas realizam treinamentos contribuindo para o desenvolvimento do padrão gerencial de destes e utilizam critérios de negociação visando o seu crescimento futuro.

O relacionamento das empresas com a comunidade baseia-se na realização de registro de reclamações da comunidade e reuniões com lideranças locais para informar as providências tomadas quanto às reclamações realizadas (Supermercados A e D). Outra postura é tomada pelos supermercados $B$ e $C$, que se antecipam e mantém comitês permanentes com a participação da comunidade a fim de analisar e monitorar os impactos e problemas advindos das atividades do supermercado.

Quanto às parcerias com organizações e grupos locais, o Supermercado A apoia várias entidades com doações, financiamento e implementação de projetos, já o Supermercado D somente responde a pedidos pontuais de apoio e doações. O Supermercados $C$ estabelece parcerias de longo prazo com entidades locais e capacita lideranças envolvidas. No entanto, o Supermercado B destacou-se com a melhor performance neste tópico, mantendo parcerias com entidades locais buscando influenciar políticas públicas, estabelecendo alianças e participando de diversas redes, a fim de maximizar sua contribuição para o desenvolvimento local.

Com relação aos indicadores para RSC e meio ambiente, destaca-se a responsabilidade e gestão dos impactos ambientais gerados pelo supermercado. Dessa forma vale destacar o seguinte: maioria dos supermercados (A, B e D) centraliza seus esforços, no que diz respeito à 
responsabilidade sobre impactos ambientais, para o cumprimento de parâmetros e requisitos da legislação ambiental brasileira. Com destaque neste grupo para a empresa B que além de cumprir com a legislação possui programas internos de melhoramento ambiental e política preventiva com atuação de um comitê responsável sobre o meio ambiente. No entanto, o Supermercado C já demonstra uma visão estratégica, pois declarou que ao desenvolver seus negócios leva em consideração os princípios da sustentabilidade ambiental e as oportunidades a ela relacionadas.

Conforme Delai e Takahashi (2008) a contribuição organizacional para o bem-estar da população e do meio ambiente ocorre pela diminuição de uso de recursos naturais, da geração de resíduos e dos impactos ocasionados aos ecossistemas terrestres, aquáticos e atmosféricos. Assim, para demonstrar a importância dada às questões ambientais na empresa, os Supermercados $A$ e $B$ têm procurado reduzir o consumo de energia, de água, de produtos tóxicos e de matérias-primas e

implantar processos para a destinação adequada dos resíduos. O Supermercado $C$ já busca investir em seu padrão tecnológico visando a redução e/ou a substituição de recursos de entrada e a reutilização de resíduos (pela própria empresa ou por terceiros). O Supermercado $D$ além de investir na redução e reutilização de recursos, possui processo para medir, monitorar e auditar periodicamente os aspectos ambientais significativos relacionados ao consumo de recursos naturais e à produção de resíduos e dejetos. Vale destacar que tal contribuição dos supermercados melhora o resultado financeiro das empresas, pois "minimizar os impactos ambientais significa otimizar o uso de materiais, prevenir multas pelo não cumprimento das leis, reduzir riscos de compensação por danos e manter a reputação" (DELAI; TAKAHASHI, 2008, p. 31).

\section{Considerações finais}

O presente estudo buscou diagnosticar as práticas de Responsabilidade Social Corporativa desenvolvidas por quatro redes de supermercados atuantes na cidade de Natal-RN, sendo duas dessas redes com atuação estritamente local e duas de atuação em todo o território nacional, através do uso de questionários direcionados aos gestores.

De forma geral, foi constatado que as práticas de RSC ocorrem mais a nível de ações internas e externas e com a prioridade no cumprimento à legislação, sendo ainda incipiente as ações consideradas estratégicas. As ações voltadas ao meio ambiente ficaram muito a desejar nas quatro empresas, com destaque, sobretudo, à falta de atuação das empresas locais para este aspecto, o que deveria ser muito mais ativa constituindo assim um exemplo para a comunidade local.

A avaliação comparativa entre as empresas estudadas possibilitou identificar os níveis de atuação de cada empresa para a RSC em três ambientes distintos: interno, externo e meio ambiente. Os resultados apontaram uma diferenciação, em algumas questões, entre supermercados de atuação local e nacional, e também dentro desses grupos, indicando que não há um padrão seguido pelas 
grandes empresas supermercadistas com relação à gestão da RSC. Além disso, as empresas locais equiparam-se, em alguns aspectos, àquelas de atuação nacional no que se refere ao bom desempenho da gestão da RSC.

Um ponto relevante verificado neste estudo foi à relação entre o tempo de atuação da empresa localmente e o nível de maturidade com a gestão da responsabilidade social. Ou seja, de modo geral, quanto maior o tempo de mercado, maior o estágio de evolução de práticas sociais em que a empresa se encontra. Além disso, a experiência do gestor bem como seu tempo de atuação na empresa são também condições determinantes para o conhecimento das demandas internas e, consequentemente, a boa gestão da RSC.

Torna-se, portanto, um desafio incluir na gestão empresarial de supermercados componentes que favoreçam a manutenção do setor no mercado de forma que este seja economicamente viável, princípios que norteiem para ações que estejam balizadas com a manutenção do equilíbrio ecológico e a adoção de indicadores de responsabilidade social que identifiquem a contribuição do setor para a melhoria da qualidade de vida, tanto interna quanto externa. A incorporação de práticas de RSC alinhadas ao negócio e dentro de uma perspectiva estratégica objetivando o ganho entre as partes envolvidas e não somente ao ganho empresarial, constitui uma forma de buscar, portanto, o desenvolvimento sustentável.

Recomenda-se, para a efetivação das práticas de RSC que haja uma maior autonomia das lojas varejistas e adequação à realidade das localidades onde se encontram, pois entende-se que as lojas que possuem uma maior descentralização em relação à matriz consegue atender melhor e mais eficazmente as necessidades de sua comunidade local. Outro ponto importante é o grau de comprometimento da matriz e a sistemática da transmissão de valores por toda a cadeia administrativa, chegando a atingir os gerentes de loja, pois estes têm um poder de atuação mais veloz sobre as práticas de RSC locais e conhecem de perto os anseios de seus colaboradores, comunidade e problemas ambientais.

Outra recomendação centraliza-se na atenção aos stakeholders com os quais a empresa se relaciona, destinando práticas de RSC a todos e não focalizando um grupo ou outro especificamente, como o que normalmente se observa (por exemplo, a preocupação com o público externo apenas). Atender aos anseios dos múltiplos agentes sociais da cadeia implica em harmonia nos negócios e ganhos para o quesito credibilidade.

\footnotetext{
Abstract

The supermarket sector, a major branch of Brazilian retail has been growing steadily over recent years in terms of income expansion and social action. In Natal (Capital of Rio Grande do Norte State) is no different. Hence, it is necessary to know how these companies have worked with focus on corporate social responsibility (CSR) in order to contribute to sustainable development. This paper discusses a case study with some supermarkets from Natal-RN, Brazil and aims to analise the
} 
social responsibility practices developed by them as a way to contribute to sustainability. Using literature as the start point, a questionnaire was developed and applied with the managers of four supermarket chains - including two local and two national networks. The questionnaire focused on the practices of CSR for the internal public, the public and the external environment. The results indicated that there was practically no difference between the performance of local and national supermarkets. In addition, CSR standards were not set by supermarkets. Basically, CSR developed by sample was focused on meeting specific demands, working to mitigate impacts on society. Key-words: corporate sustainability; corporate social responsibility; sustainability indicators; supermarkets.

\section{Referências}

ALIGLERI, L. Gestão Estratégica da Responsabilidade Social em Supermercados: uma proposta para o processo de engajamento. CONGRESSO LATINO AMERICANO DE VAREJO, 1., 8 e 9 out. 2008, São Paulo. Anais eletrônicos .... São Paulo, 2008. Disponível em:

<http://varejosustentavel1.tempsite.ws/painel/dbarquivos/dbanexos/1_gestoestratgicadarsemsupermercadosp.pdf>. Acesso em: 23 mar. 2010.

ASSOCIAÇÃO PAULISTA DE SUPERMERCADOS - APAS. Guia prático APAS: supermercado sustentável. São Paulo: 2008. Disponível em:

<http://varejosustentavel1.tempsite.ws/painel/dbarquivos/dbanexos/guiaprticoapassupermercadosustentvelp.pdf >. Acesso em: 23 mar. 2010.

CARDOSO, R. Especial: varejo. Varejo Sustentável. GV Executivo. v.7, n. 5, set/out, 2008.

CONSELHO NACIONAL DO MEIO AMBIENTE. Resolução No 257, de 30 de junho de 1999. Disponível em: < http://www.mma.gov.br/port/conama/res/res99/res25799.html>. Acesso em: 19 abr. 2010.

DAVID, A. F. Balanço social: uma análise das informações evidenciadas pelas empresas.In: CONVENÇÃO DE CONTABILIDADE DO RIO GRANDE DO SUL, 9., 13 a 15 agos. 2003, Gramado, RS. Anais... Gramado, RS, 2003. Disponível em: 〈http://ccontabeis.com.br/conv/t30.pdf >. Acesso em: 4 mar. 2010.

DELAI, I.; TAKAHASHI. Uma proposta de modelo de referência para mensuração da sustentabilidade corporativa. RGSA- Revista de Gestão Social e Ambiental, v. 2, n.1, p. 19-40, jan. /abr. 2008.

DIAS, R. Gestão ambiental: responsabilidade social e sustentabilidade. 1. ed. São Paulo: Atlas, 2008.

ETHOS, INSTITUTO. Indicadores Ethos de Responsabilidade Social Empresarial. São Paulo: Instituto Ethos, 2007. Disponível em: < www.ethos.org.br >. Acesso em: 2 out. 2008.

FURTADO, R.; PENA, R. P. M. Responsabilidade social com o público interno: a percepção dos empregados da Promom. Revista de Gestão Social e Ambiental, v. 1, n. 3, set/dez, 2007.

GIL, A.C. Como elaborar projetos de pesquisa. São Paulo: Atlas, 2006.

HOLME, R.; WATTS, P. Responsabilidade social empresarial (rse): bom senso aliado a bons negócios, [S.1.: s.n.], 2000. Disponível em: <http://www.cebds.org.br/cebds/pub-docs/pub-rse-bom-senso-aliado-negocios.pdf>. Acesso em: 25 fev. 2010.

INSTITUTO ETHOS. Indicadores de SER. [Rio de janeiro], 2008. Disponível em: < http://www.ethos.org.br/_Uniethos/documents/IndicadoresEthos_port.pdf>. Acesso em: 23 fev. 2010.

KUHNDT, M. Sustainable business development. In: SEILER, Hausmann Jan Dirk; LIEDTKE, Chista; WEIZSÄCKER, Ernst U. Von (Orgs.). Eco-efficiency and beyond: toward the sustainable enterprise. Sheffield: Greenleaf Publishing, 2004. 248 p.

ORCHIS, M. A.; YUNG, M. T.; MORALES, S. C. Impactos da responsabilidade social nos objetivos e estratégias empresariais. In:___. Responsabilidade social das empresas: a contribuição das universidades. São Paulo: Peirópolis: Instituto Ethos, 2002. v.1 
PARENTE, J. G.; TEREPINS, F. M. Responsabilidade social empresarial do varejo no Brasil: um estudo multicasos em empresas de grande porte. SIMPÓSIO DE ADMINISTRAÇÃO DA PRODUÇÃO, LOGÍSTICA E OPERAÇÕES INTERNACIONAIS 9, 2006, São Paulo. Anais... São Paulo: FGV - EAESP, SIMPOE, 2006.

PEREIRA, W. A.; FILHO, L. A. N. C. Investigação sobre as semelhanças entre os modelos conceituais da responsabilidade social corporativa. Revista de Gestão Social e Ambiental, v.1, n.1, 2007.

PRIMOLAN, L. V. A responsabilidade social corporativa como um fator de diferenciação na competitividade das organizações. Revista Gerenciais, São Paulo: UNINOVE, v. 3, p. 125-134, out. 2004.

SCHROEDER, J. T.; SCHROEDER, I. Responsabilidade social corporativa: limites e possibilidades. ERA Eletrônica, São Paulo, v. 3, n. 1, 2005.

SECRETARIA ESTADUAL DE TRIBUTAÇÃO DO RIO GRANDE DO NORTE - SET. Supermercados crescem 32\% e faturam 1,6 bilhão. Natal, [200-?]. Disponível em:<

http://www.set.rn.gov.br/set/noticias/arquivos/not/24abr2006\%20-

$\% 20$ Supermercados\%20crescem\%20e\%20faturam\%20R \$\%201,6\%20bilh\%C3\%A3o.htm>. Acesso em: 26 fev. 2010.

TACHIZAWA, T.; ANDRADE, R. B. Gestão socioambiental: estratégias na nova era da sustentabilidade. Rio de Janeiro: Elsevier, 2008.

TOLDO, M. Responsabilidade social empresarial. In: Responsabilidade social das empresas: a contribuição das universidades. São Paulo: Peirópolis: Instituto Ethos, 2002. v.1

TREVISAN, F. A. Balanço social como instrumento de marketing. RAE-eletrônica, v.1, n.2, 2002. crosssref

\section{Apêndice A - descrição das chaves de resposta das variáveis analíticas adotadas}

\begin{tabular}{|c|c|c|}
\hline Grupo & Variável & Escala de resposta (nível de maturidade) \\
\hline \multirow{9}{*}{ 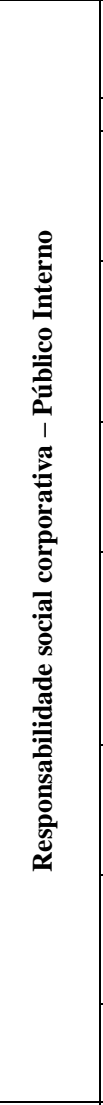 } & QGPI-1 & $\begin{array}{l}\text { 0-Sem Opinião; 1-Ainda não foi adotado um processo de difusão estruturado; 2-Carta de Princípios pouco } \\
\text { incorporada/disseminada; 3-Documento Formal com processo de difusão sistematizado; 4-Código de Conduta difundido em } \\
\text { todos os níveis hierárquicos e de forma sistematizada }\end{array}$ \\
\hline & QGPI-2 & 0-Sem Opinião; 1-Inexistente; 2-Eventos Pontuais; 3-Periodicamente; 4-Permanentemente. \\
\hline & QGPI-3 & $\begin{array}{l}\text { 0-Sem Opinião; 1-Não trabalha questões de RSC; 2-Há um profissional responsável pelas questões de RSC atuando de } \\
\text { forma pontual dentro de um setor não específico; 3-Há um setor específico para trabalhar estas questões de forma } \\
\text { sistematizada e periódica; 4- A RSC é trabalhada de forma transversal e contínua dentro da empresa, dentro de um setor } \\
\text { próprio e sob coordenação de um profissional especializado na área }\end{array}$ \\
\hline & QGPI-4 & $\begin{array}{l}\text { 0-Sem Opinião; 1-Dispõe de informações sobre a empresa e treina os empregados para melhor conhecê-las; 2-Além do } \\
\text { anterior, ainda disponibiliza aos empregados informações econômico-financeiras da empresa; 3-Além dos anteriores, tem } \\
\text { um processo estruturado de discussão e análise de riscos e oportunidades com seus empregados sobre questões econômico- } \\
\text { financeiras da empresa; 4- Além dos anteriores, representantes dos empregados participam ativamente das decisões } \\
\text { estratégicas da empresa }\end{array}$ \\
\hline & QGPI-5 & $\begin{array}{l}\text { 0-Sem Opinião; } 1 \text {-Discute o assunto com empregados e trata de casos isolados e esporadicamente; 2-Somente garante os } \\
\text { direitos da legislação em vigor relativos à proteção à maternidade e paternidade; 3-Além do item anterior, ainda apresenta } \\
\text { ações pontuais voltadas para benefício/auxílio dos filhos de funcionários; 4-Desenvolve projetos permanentes que } \\
\text { contribuem para o desenvolvimento dos filhos de seus empregados }\end{array}$ \\
\hline & QGPI-6 & $\begin{array}{l}\text { 0-Sem Opinião; } 1 \text {-Somente discute e orienta os empregados contra a descriminação social e promove a equidade racial; 2- } \\
\text { Declara a não descriminação social e racial e promove a igualdade de oportunidades no ambiente interno; 3-Além disso, } \\
\text { promove a diversidade social e equidade racial interna por meio de avisos e normas escritas, orientando para possíveis } \\
\text { denúncias; 4-Além do anterior ainda realiza treinamentos e seminários específicos estimulando a conscientização sobre os } \\
\text { temas e utiliza critérios de seleção não discriminatórios em relação a gênero, raça, orientação sexual, idade, crenças } \\
\text { religiosas, bem como a pessoas com deficiências }\end{array}$ \\
\hline & QGPI-7 & $\begin{array}{l}\text { 0-Sem Opinião; 1-Somente garante os pisos salariais firmados com sindicatos; 2-Busca superar os pisos salariais firmados;3- } \\
\text { Trata os empregados como um recurso, estimulando-os através da remuneração e investindo em seu desenvolvimento } \\
\text { profissional; 4-Além do item anterior, valoriza competências potenciais levando em conta sua capacidade de crescimento e } \\
\text { desenvolvimento de novas habilidades adotando inclusive uma política de progressão funcional. }\end{array}$ \\
\hline & QGPI-8 & $\begin{array}{l}\text { 0-Sem Opinião; 1-Cumpre rigorosamente as obrigações legais; 2-Além do anterior ainda possui planos e metas para } \\
\text { ultrapassar os padrões de excelência na área; 3-Além do anterior, desenvolve campanhas regulares de conscientização e } \\
\text { pesquisa o nível de satisfação dos empregados para melhor atendê-los; 4-Além do anterior ainda conta com a participação } \\
\text { do empregado para a definição de metas e indicadores de desempenho das condições do trabalho, saúde e segurança. }\end{array}$ \\
\hline & $\begin{array}{l}\text { QGPI-9- } \\
\text { a,b,c,d,e,f, } \\
\text { g }\end{array}$ & $\begin{array}{l}\text { 0-Sem Opinião; 1-Ação não Implementada; 2-Estudando Viabilidade; 3-Em processo de Implementação; 4-Ação } \\
\text { Implementada }\end{array}$ \\
\hline \multirow{3}{*}{ 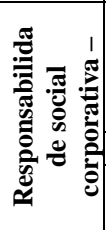 } & QGPE-1 & $\begin{array}{l}\text { 0-Sem Opinião; 1-Publicação impressa nos murais dos setores da empresa; 2-No momento de treinamento dentro do } \\
\text { processo de admissão de funcionários; 3-Em ocasiões periódicas quando há treinamentos ou reunião com representantes de } \\
\text { todos os setores da empresa; 4- Disseminada continuamente por todos os funcionários através da incorporação voluntária e } \\
\text { da influencia do exemplo de seus coordenadores setoriais }\end{array}$ \\
\hline & QGPE-2 & 0-Sem Opinião; 1-Inexistente; 2-Eventos Pontuais; 3-Periodicamente; 4-Permanentemente \\
\hline & QGPE-3 & $\begin{array}{l}\text { 0- Sem Opinião; 1- Nunca; 2- Em processo de implantação; 3-Implantado mas não respeita a periodicidade; 4- Implantado e } \\
\text { com Publicação Periódica }\end{array}$ \\
\hline
\end{tabular}




\begin{tabular}{|c|c|}
\hline QGPE-4 & $\begin{array}{l}\text { 0-Sem Opinião; 1-Possui política de seleção e avaliação baseada somente em critérios de qualidade, preço e prazo; 2-Além } \\
\text { do item anterior, possui normas de seleção e avaliação de fornecedores contemplando critérios de cumprimento da legislação } \\
\text { trabalhista, previdenciária e fiscal; 3-Além dos itens anteriores suas normas de seleção e avaliação ainda incorporam } \\
\text { critérios de responsabilidade social; 4-Apresenta todos os itens anteriores e realiza o monitoramento periódico destes } \\
\text { critérios. }\end{array}$ \\
\hline QGPE-5 & $\begin{array}{l}\text { 0- Sem Opinião; 1-Negocia com transparência e estabelece relações contratuais independentemente do porte do fornecedor; } \\
\text { 2-Promove atividades conjuntas de treinamento contribuindo para o desenvolvimento do padrão gerencial de fornecedores; } \\
\text { 3-Contribui para a melhoria gerencial de fornecedores e utiliza critérios de negociação com vistas em seu crescimento } \\
\text { futuro; 4-Além de contribuir com o desenvolvimento/crescimento de fornecedores de igual ou menor porte, ainda o estimula } \\
\text { e facilita seu envolvimento em projetos sociais e ambientais. }\end{array}$ \\
\hline QGPE-6 & $\begin{array}{l}\text { 0-Sem Opinião; 1-Procura tomar medidas reparadoras em resposta às reclamações da população; 2-Conhece o seu potencial } \\
\text { de geração de impacto, possui processo de registro de reclamações e promove reuniões com lideranças locais para informar } \\
\text { as providências tomadas; 3- Antecipa-se às demandas da comunidade informando-as sobre atuais e futuros planos e } \\
\text { impactos de sua atividade, envolvendo a comunidade na resolução dos problemas; 4-Além do item anterior ainda mantém } \\
\text { comitês permanentes com a participação da comunidade a fim de analisar e monitorar os impactos de sua atividade. }\end{array}$ \\
\hline QGPE-7 & $\begin{array}{l}\text { 0-Sem Opinião; 1-Conhece suas atividades e responde a pedidos pontuais de apoio a projetos; 2-Apoia várias entidades com } \\
\text { doações, financiamento e implementação de projetos e ainda divulga experiências bem sucedidas; 3- Participa da elaboração } \\
\text { e implementação de projetos e estabelece parcerias de longo prazo capacitando lideranças envolvidas; 4-Mantém parcerias } \\
\text { com entidades locais buscando influenciar políticas públicas, estabelecendo alianças e participando de diversas redes, a fim } \\
\text { de maximizar sua contribuição para o desenvolvimento local. }\end{array}$ \\
\hline QGPE-8 & $\begin{array}{l}\text { 0-Sem Opinião; } 1 \text {-Desenvolve atividades eventuais com foco na educação para a cidadania com o entendimento de direitos e } \\
\text { deveres de uma sociedade; } 2 \text {-Desenvolve atividades periódicas para a promoção da cidadania permitindo a livre discussão } \\
\text { sobre temas políticos; 3-Promove ou apoia a realização de debates e fóruns sobre cidadania inclusive quando há discussão } \\
\text { com candidatos a cargos eletivos, objetivando assegurar o voto consciente; 4-Desenvolve programas de educação para a } \\
\text { cidadania tanto internamente quanto em sua cadeia de produção e comunidade local, exercendo sua liderança na discussão } \\
\text { de temas como a participação popular e combate a corrupção. }\end{array}$ \\
\hline $\begin{array}{l}\text { QGPE-9- } \\
\text { a,b,c,d,e,f }\end{array}$ & $\begin{array}{l}\text { 0-Sem Opinião; 1-Ação não Implementada; 2-Estudando Viabilidade; 3-Em processo de Implementação; 4-Ação } \\
\text { Implementada. }\end{array}$ \\
\hline
\end{tabular}

\section{Apêndice A - Descrição das chaves de resposta das variáveis analíticas adotadas}

\section{(Continuação)}

\begin{tabular}{|c|c|c|}
\hline $\begin{array}{c}\text { Gr } \\
\text { upo }\end{array}$ & Variável & Escala de resposta (nível de maturidade) \\
\hline \multirow{4}{*}{ 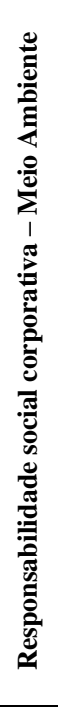 } & QGMA-1 & $\begin{array}{l}\text { 0-Sem Opinião; 1-Cumpre os parâmetros e requisitos exigidos pela legislação nacional; 2-Além de cumprir com a } \\
\text { legislação, possui programas interno de melhoramento ambiental e possui política preventiva com atuação de um comitê } \\
\text { responsável sobre o meio ambiente; 3-Trata a questão ambiental como tema transversal em sua estrutura organizacional e a } \\
\text { inclui no planejamento estratégico; 4-Ao desenvolver novos negócios, leva em consideração os princípios da } \\
\text { sustentabilidade ambiental e as oportunidades a ela relacionadas. }\end{array}$ \\
\hline & QGMA-2 & $\begin{array}{l}\text { 0-Sem Opinião; 1-Desenvolve ações de educação ambiental e treinamentos com funcionários sobre a temática de forma } \\
\text { pontual ou devido a pressão externa; } 2 \text { - Desenvolve um processo sistemático de educação ambiental com o público interno } \\
\text { disponibilizando informações e estimulando discussões; } 3 \text { - Além do programa interno, desenvolve também campanhas de } \\
\text { educação ambiental dirigidas a familiares, fornecedores, cliente/consumidores e comunidade do entorno; 4-Além de } \\
\text { desenvolver programas internos e campanhas para público externo, ainda apoia ou participa de projetos em parceria com } \\
\text { ONGs e ambientalistas, exercendo liderança social em favor desta causa }\end{array}$ \\
\hline & QGMA-3 & $\begin{array}{l}\text { 0-Sem Opinião; 1-Produz estudos de impacto ambiental segundo exigências da legislação e foca sua ação preventiva nos } \\
\text { processos que oferecem dano potencial a saúde e risco a segurança de seus empregados; 2-Além de cumprir a legislação, } \\
\text { conhece e desenvolve ações para prevenir os principais impactos ambientais causados por seus processos e produtos ou } \\
\text { serviços e realiza regularmente atividades de controle e monitoramento; 3-Possui sistemas de gestão ambiental padronizados } \\
\text { e formalizados, incluindo ampla identificação de riscos, plano de ação, alocação de recursos, treinamento de empregados e } \\
\text { auditoria; 4-Além de possuir um SGA, produz estudos de impacto em toda a cadeia produtiva; desenvolve parceria com } \\
\text { fornecedores visando a melhoria de seus processos de gestão ambiental e participa da destinação final dos produtos e } \\
\text { processos pós-consumo. }\end{array}$ \\
\hline & $\begin{array}{l}\text { QGMA-4- } \\
\text { a,b,c,d,e,f, } \\
\text { g,h }\end{array}$ & $\begin{array}{l}\text { 0-Sem Opinião; 1-Ação não Implementada; 2-Estudando Viabilidade; 3-Em processo de Implementação; 4-Ação } \\
\text { Implementada. }\end{array}$ \\
\hline
\end{tabular}

\section{Dados dos autores}

\section{Nome completo: Handson Cláudio Dias Pimenta}

Filiação institucional: Instituto Federal de Educação, Ciência e Tecnologia do Rio Grande do Norte

Departamento: Recursos Naturais. Núcleo de Estudos em Sustentabilidade Empresarial.

Função ou cargo ocupado: Professor / Pesquisador

Endereço: Rua das Hortênsias, 395, Mirassol. Natal-RN. 59078-140.

Telefone: (84) 9134-7074

e-mail: handson.pimenta@ifrn.edu.br 
Nome completo: Ana Clézia Simplício de Morais

Filiação institucional: Universidade Federal do Rio Grande do Norte

Função ou cargo ocupado: Pesquisadora

e-mail: clezia_ecologia@yahoo.com.br

Submetido em: 04/09/2013

Aceito em: 10/10/2014 